\title{
Triquetrella mxinwana, a new moss species from South Africa, with a phylogenetic and biogeographic hypothesis for the genus
}

\author{
TERRY A. HEDDERSON ${ }^{1}$ and RICHARD H. ZANDER ${ }^{2}$ \\ ${ }^{1}$ University of Cape Town, South Africa and ${ }^{2}$ Missouri Botanical Garden, St Louis, U.S.A.
}

\begin{abstract}
SUMMARY
We describe Triquetrella mxinwana, a new species presently known only from the winter rainfall area of South Africa. Within this region it is common in karroo and renosterveld, but it also occurs in fynbos. It differs from other Triquetrella species in the several low, bifid, papillae on each laminal cell, but is similar to the Australian Leptodontium paradoxum, differing in size and anatomical details. Although sporophytes of L. paradoxum are unknown, those of T. mxinwana have the peristome of Triquetrella rather than Leptodontium. Phylogenetic analysis of data from three chloroplast (rps $4, \operatorname{trn} \mathrm{L}-\mathrm{F}$ and $p s b \mathrm{~A}-\operatorname{trn} \mathrm{H})$ and one nuclear (ITS1) loci confirms that T. mxinwana and L. paradoxum are sister taxa and together are sister to the rest of Triquetrella. This placement also better reflects gametophyte morphology, which, though intermediate between Triquetrella and Leptodontium, better fits the former. Divergence levels among species of Triquetrella are very low and molecular clock approaches indicate that all divergences are of Pliocene-Pleistocene age. The estimated time of the split between T. mxinwana and its nearest relative is concordant with independent paleoclimatic estimates of the time of onset of winter rainfall conditions in the Cape. The disjunctive distribution of the genus in areas of Mediterranean climate is attributed to dispersal rather than ancient vicariance.
\end{abstract}

KEYWORDS: Triquetrella, Mediterranean climate disjuncts, Pliocene-Pleistocene dispersal, Cape flora, xerothermic Pangaean elements, Leptodontium, new South African Triquetrella.

\section{Introduction}

Triquetrella Müll.Hal. is a small genus of morphologically similar species found on soil or rock, and largely restricted to dry, Mediterranean climates in Europe (Spain), South Africa, western North America (California), southern South America, Australia, Tasmania and New Zealand (Stark, 1980; Magill, 1981; Casas, Cros \& Muñoz, 1993; Zander, 1993). A distinctive suite of features characterizes the genus, at least as conceived by Zander (1993). The stems are triangular in section, with the central strand lacking (or extremely reduced). Leaves are arranged in three distinct rows that often spiral about the stem and have long, broadly decurrent, margins that remain on the stem when the leaves are stripped off, resulting in distinctive curling fragments attached to stem sections. The costae are percurrent, with two stereid bands (the ventral of few cells or occasionally absent) in section. Laminal cells have a single narrow, spiculose papilla that is simple or branching from the base and the basal cells are little or not differentiated. Perichaetial leaves are enlarged, sheathing

(C) British Bryological Society 2007

DOI: $10.1179 / 174328207 X 205171$ the base of the seta, and have smooth, elongate laminal cells. The peristome is whitish, consisting of 16 short teeth that are split to the base, and smooth or weakly spiralstriate. The laminal $\mathrm{KOH}$ colour reaction is orange or yellow-orange.

Of the species listed by Zander (1993), T. spiculosa Thér. has been placed in synonymy with Zygodon pichinchensis (Churchill, Griffin \& Muñoz, 2000). We have also been able to examine Type material (BM, $\mathrm{H}-\mathrm{Br}$ and $\mathrm{G}$ ) of the Australian species $T$. fragilis Müll.Hal. and T. richardsiae Müll.Hal. as well as of the South American T. filicaulis Dusén, and in our opinion these are indistinguishable, respectively, from T. papillata (Hook. f. \& Wilson) Broth. and T. patagonica Müll.Hal. Triquetrella tasmanica (Broth.) Granzow, transferred to the genus from Anomodon, is, on the basis of our unpublished analyses of rps 4 and $\operatorname{trn} L-F$ sequences, a member of the 'ciliate arthrodonts' (sensu Cox \& Hedderson, 1999) rather than the Dicranidae, and can therefore also be eliminated from consideration. There thus remain five species in the genus: Triquetrella arapilensis Luisier, T. californica (Lesq.) Grout, T. papillata, $T$. 
patagonica and T. tristicha (Müll.Hal.) Müll.Hal., all of which have a single, usually branching but occasionally simple, papilla per lumen.

Triquetrella differs from Leptodontium in: (1) the short, triangular cauline leaves form three distinct rows; (2) the occasional presence of a stem central strand (in $T$. californica) as opposed to its consistent absence; and (3) sharp, spiculose upper laminal papillae, as opposed to the usually multiplex or, in sect. Leptodontium, blunt and simple to columnar papillae found in Leptodontium. Although Eddy (1990) suggested, without further elaboration, that Triquetrella might be misplaced in the Pottiaceae, molecular analyses that have included representatives of the genus consistently refute this (Werner et al., 2004; T. A. Hedderson \& R. A. Zander, unpublished); in all such analyses, Triquetrella is resolved as sister to Leptodontium, and this clade is well nested within Pottiaceae.

Leptodontium paradoxum I. G. Stone \& G.A.M.Scott is an Australian species that is somewhat intermediate between the two genera (Stone \& Scott, 1981). Although it has many of the features of Leptodontium, including multiple papillae per cell, it shares with Triquetrella two traits rare in the former genus: entire leaves and a differentiated dorsal epidermis (Zander, 1993). Sporophytes, which would help determine placement, have not been found for this species.

An apparently undescribed South African species, represented by a considerable number of specimens gathered over the span of many years by numerous collectors, is similar to this Australian species. However, the South African material is uniformly smaller, by about half, than the Australian species in leaf dimensions and in diameter and length of stems, and also differs in its anatomical details. While only perigonia, not perichaetia, have been found in Australia, some of the South African specimens include sporophytes and these demonstrate the peristome of Triquetrella, not that of Leptodontium.

In this paper we present our arguments for recognizing the new South African species. We use molecular data to evaluate phylogenetic relationships between Triquetrella and Leptodontium and, in particular, we determine the positions of $L$. paradoxum and the new species. Since we have complete sampling of the known Triquetrella species we also comment on the biogeographical implications of the phylogeny.

\section{Methods}

\section{Taxon and locus sampling}

We sampled all five of the species remaining in Triquetrella, L. paradoxum, the putative new species and two additional species of Leptodontium. In the case of Triquetrella, five of the species are represented by at least two accessions (Table 1). Tetrapterum tetragonum was used to root the tree, on the basis of our unpublished phylogeny of the Pottiaceae. Using other potential Pottiaceeous outgroups (e.g. Didymodon spp., Trichostomum spp., Tortula spp.) for which we have rps4 and/or trnL-trnF information did not affect placement of the root.

The four DNA regions sampled include three from the chloroplast (the $p s b \mathrm{~A}-t r n \mathrm{H}$ spacer, the $\operatorname{trn} \mathrm{L}-\operatorname{trn} \mathrm{F}$ region and the rps 4 gene region) and a single nuclear locus (the first internal transcribed spacer (ITS1) of the 18S-26S rRNA cistron). All have been used previously for recovering species and lower-level phylogenies (e.g. Sang, Crawford \& Stuessy, 1997; Chandler, Bayer \& Crisp, 2001; Cox \& Hedderson, 2004; Hedderson \& Nowell 2006).

\section{Sequence generation and alignment}

DNA extraction, PCR amplification of target regions, and subsequent sequencing of PCR products followed procedures outlined in Hedderson \& Nowell (2006). Primers 18KRC (Hedderson \& Nowell, 2006) and ITS2 (Baldwin, 1992) were used to amplify the nuclear ribosomal ITS1

Table 1. Voucher information and Genbank Accession numbers for specimens sampled. Vouchers deposited at BOL unless otherwise indicated.

\begin{tabular}{|c|c|c|c|c|c|}
\hline Species & Voucher specimen & rps 4 & TrnL-F & PsbA-trnH & ITS1 \\
\hline Triquetrella arapilensis & Spain, Ciudad Real. Fuertes s.n. MA & AM491747 & AM491741 & AM497952 & AM497938 \\
\hline T. californica & U.S.A., California. Whittemore 6712, MO & AM491748 & AM491742 & AM497953 & AM497939 \\
\hline T. papillata 1 & Australia, New South Wales. Coveny 17500 , MO & AM491749 & AM491743 & AM497954 & AM497940 \\
\hline T. papillata 2 & Australia, W. Australia. Moore s.n., MO & AM491750 & AM491744 & AM497955 & AM497941 \\
\hline T. patagonica 1 & Chile, Ñuble. Ireland 32767 & AM491752 & AM491745 & AM497956 & AM497942 \\
\hline T. patagonica 2 & Chile, Concepción. Ireland 32281 & AM491751 & AM491746 & AM497957 & AM497943 \\
\hline T. sp. nov 1 & South Africa, Western Cape. Hedderson 13514 & AM491753 & AM497784 & AM497958 & AM497944 \\
\hline T. sp. nov. 2 & South Africa, Western Cape. Hedderson 13539 & AM491754 & AM497785 & AM497959 & AM497945 \\
\hline T. sp. nov. 3 & South Africa, Western Cape. Hedderson 15208 & AM491755 & AM497786 & AM497960 & AM497946 \\
\hline T. tristicha 1 & South Africa, Western Cape. Hedderson 13843 & AM491756 & AM497787 & AM497961 & AM497947 \\
\hline T. tristicha 2 & South Africa, Western Cape. Hedderson 14527 & AM491757 & AM497788 & AM497962 & AM497948 \\
\hline Leptodontium paradoxum 1 & Australia, New South Wales. Vitt 27377, MO & AM491758 & AM497789 & AM497963 & AM497949 \\
\hline L. paradoxum 2 & Australia, Victoria. Stajsic 2559, MEL & AM491759 & AM497790 & AM497964 & AM497950 \\
\hline L. wallisii & Equador, Azuay. Price 27, MO & AM491760 & AM497791 & AM497965 & NA \\
\hline L. gemmascens & U.K., Somerset. Hedderson 12996, Herb TAH & AM491761 & AM497792 & AM497966 & AM497951 \\
\hline Tetrapterum tetragonum & South Africa, Western Cape. Hedderson 14305 & AM491762 & AM497793 & NA & NA \\
\hline
\end{tabular}


region. The chloroplast $r p s 4$, $\operatorname{tr} n \mathrm{~L}-\mathrm{F}$ and $p s b \mathrm{~A}-\operatorname{trn} \mathrm{H}$ regions were amplified using primers given in Nadot et al. (1995), Taberlet et al. (1991) and Sang et al. (1997), respectively. Assembled sequences were aligned manually using MegAlign (Lasergene System Software). In addition to nucleotide polymorphisms, we identified 21 insertion/ deletion events that were coded as presence/absence characters. The psbA-trnH and ITS regions for Tetrapterum were highly divergent from, and could not be reliably aligned against, those of the ingroup taxa. These were therefore treated as missing for the outgroup. Low levels of divergence (see below) rendered alignment of ingroup sequences unproblematic.

\section{Data analyses}

The data were analysed under the parsimony criterion, as well as under a maximum likelihood criterion employing a Bayesian approach to estimate jointly the topology, branch lengths and parameters of the substitution model. Parsimony analyses used the branch and bound algorithm of PAUP 4.0b10 (Swofford, 1998) to recover all optimal trees. Nodal support was evaluated by the parsimony jackknife (Farris et al., 1996) as implemented in PAUP $4.0 \mathrm{~b} 10$, using 1000 replicates. At each replicate $36.79 \%$ of characters were deleted, and the 'emulate Jac' option was enforced.

Bayesian analyses were undertaken using MrBayes 3 (Ronquist \& Huelsenbeck, 2003). Prior analyses using Modeltest (Posada \& Crandall, 1998) indicated that a general time-reversible model of DNA substitution, incorporating among-site rate heterogeneity as modelled by a gamma distribution plus a proportion of invariant characters $(\mathrm{GTR}+\mathrm{I}+\mathrm{G})$ provided the best fit to each of the separate DNA regions. Parameters were unlinked across the four data partitions. The analysis used four chains (one cold and three heated), and was run for 2000000 generations. Model parameters, including trees, were sampled every 10 generations. The number of generations needed to reach stationarity (i.e. the 'burnin') was estimated by visual inspection of the plot of ML scores at each sampling point. The trees of the burnin from each chain were excluded from the tree set. The remaining trees were combined to form the full sample, which we assume to represent the posterior probability distribution of trees.

\section{Results}

The four regions yielded 119 variable characters, including 21 indels (Table 2). Of these, 41 characters have potential phylogenetic information under the parsimony criterion.

Topologies recovered under parsimony and Bayesian analyses are identical (Fig. 1). The traditionally defined Triquetrella species form a strongly supported group to which an equally well-supported clade, comprising Leptodontium paradoxum and the new South African species, is placed with strong support as sister.

Accessions of the new South African species and L. paradoxum form reciprocally monophyletic groups (in each case with strong support) united, respectively, by five and six unique changes including at least one character from each locus used. One of the unique changes characterizing the L. paradoxum accessions is the insertion of a codon (ACA, i.e. threonine) at a point corresponding to amino acid position 37 relative to Funaria hygrometrica Hedw. Reciprocal monophyly of the two species, at least as sampled here, is probabilistically assured because the accessions are supported by two internodes with Bayesian posteriors of 0.98 and 1 , the joint probability of which supports recognition of the two lineages as a set at the $95 \%$ level.

The remaining Triquetrella species show few differences across the four regions analysed here. Triquetrella arapilensis and the two $T$. tristicha specimens are identical. Triquetrella californica and the two $T$. patagonica accessions are identical to each other, and are united relative to the rest of the species by a single, homoplasious, indel in the ITS region. These two are further united with the $T$. papillata accessions by a single, albeit unique, third-base transition in the rps 4 region.

\section{Discussion}

The data from the four DNA loci examined here provide strong support for the placement of $L$. paradoxum and the multi-papillose South African specimens in the relationship of Triquetrella rather than Leptodontium. On the basis of the phylogeny presented above, morphological synapomorphies for this expanded concept of Triquetrella would include triangular (to rarely five-sided) stems usually lacking a central strand, ovate-triangular leaves with distinctively decurrent margins, and the form of the

Table 2. Summary of phylogenetic characteristics for each of the four DNA regions utilized in this study. The values given for the ITS region exclude the $18 \mathrm{~S}$ portions of the amplicon.

\begin{tabular}{|c|c|c|c|c|c|}
\hline DNA region & Alignment length & Indels & Variable/\% & Phylogentically informative $/ \%$ & CI \\
\hline$r p s 4$ & 613 & 1 & $39 / 6.4$ & $21 / 3.4$ & 0.90 \\
\hline $\operatorname{trn} L-F$ & 437 & 9 & $39 / 8.9$ & $14 / 3.2$ & 0.79 \\
\hline psbA-trnH & 172 & 4 & $11 / 6.4$ & $08 / 4.6$ & 1.00 \\
\hline ITS 1 & 292 & 7 & $29 / 9.9$ & $09 / 3.1$ & 0.90 \\
\hline Total & 1867 & 21 & $118 / 6.3$ & $52 / 2.8$ & 0.87 \\
\hline
\end{tabular}




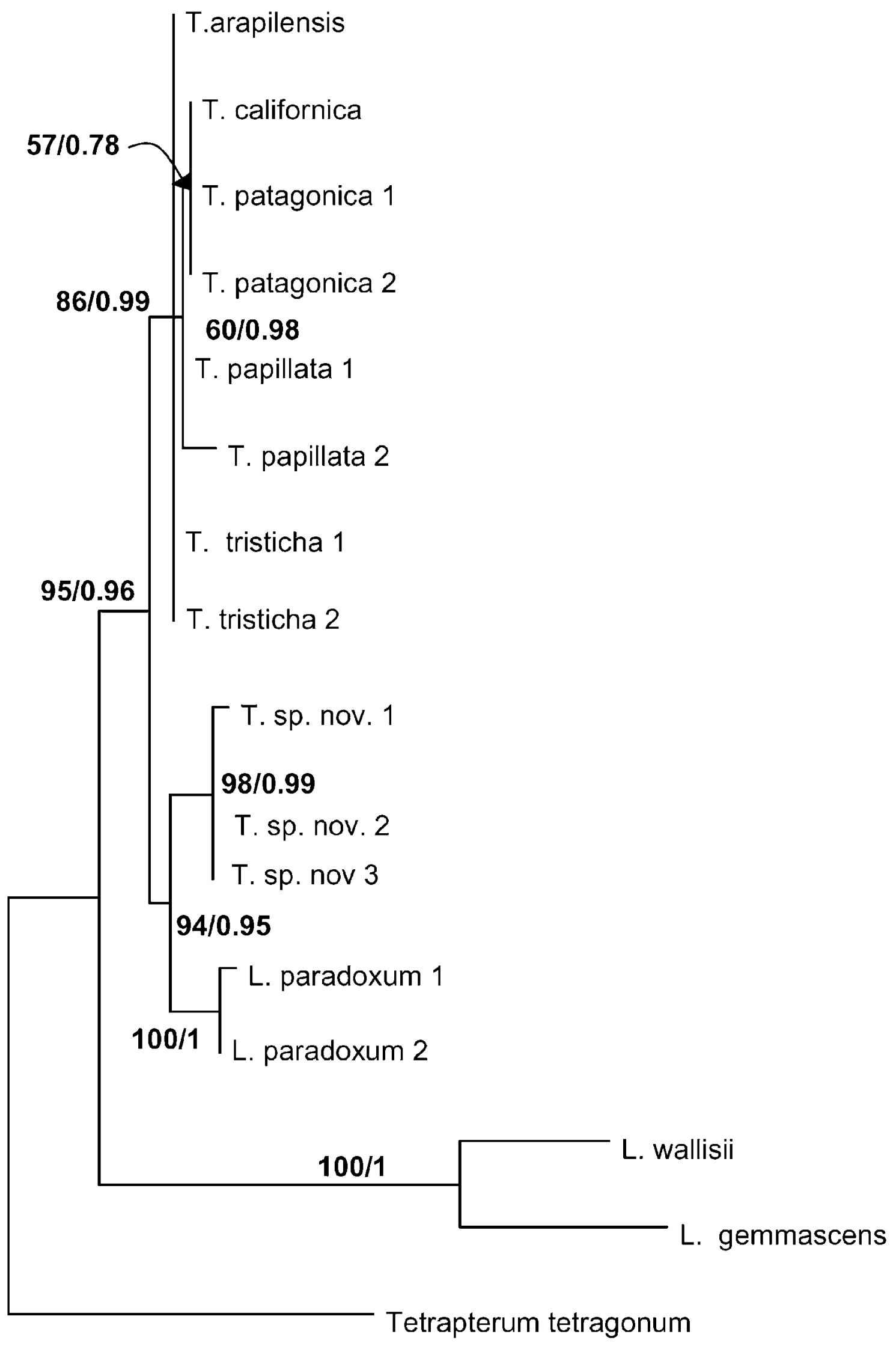

Figure 1. Phylogenetic relationships of Triquetrella recovered under Bayesian analysis of sequence variation at ITS1 rps4, trnl-F and $p s b A$ $\operatorname{trn} H$ loci. Topologies recovered under the parsimony criterion were identical. Numbers given at nodes are jackknife proportions/Bayesian posterior probabilities. 
perichaetial leaves and peristome. The remaining features listed in the introduction as characteristic of Triquetrella are potential synapomorphies (at least at this level of universality) for the traditionally defined genus, hereafter referred to as the 'core' Triquetrella clade. Thus the character of multiple papillae per cell is to be seen as a symplesiomorphy shared by $T$. paradoxa (formally transferred below) and the multi-papillose Cape material, whilst spiculose papillae are a synapomorphy for the core clade. Given its position in the phylogeny, the occasional presence of a central strand in T. californica must be interpreted as a reversal and raises some interesting questions about the genetic control of morpho-anatomical characters in Pottiaceae, suggesting that the loss of this trait may be due to functional changes in a single gene (cf. Zander, 2006).

Given the distinction of the molecular markers, the consistent trait of relatively small size of mature plants in all the many South African collections compared with $T$. paradoxa (leaves about one-third the length of those of the latter), and the distinctive anatomical details listed below, we here describe the species as T. mxinwana. The Australian populations differ in the gain of a codon in the rps 4 coding region relative to all the other accessions. Insertion-deletion events are rare in this region, and in broad samplings across all the mosses (Goffinett, Shaw \& Hedderson, 2001; Hedderson et al., 2004) only two have been identified previously - one characterizing the Funariaceae, and the other Octoblepharum. We take this as further support for recognition of two separate multipapillose species.

Strong similarities among the species of Triquetrella have been noted previously (Casas et al., 1993; Zander, 1993) and, except for the T. mxinwana and T. paradoxa pair, the species are much alike. For the core species, somewhat subtle differences, as summarized by Casas et al. (1993), exist in length of the theca, leaf shape, acumination of the leaf apex, length of the decurrencies, and in presence or absence of the stem central strand. It is not clear, on the other hand, how reliably one could differentiate among these without information on provenance.

The distribution of Triquetrella, like that of a number of other bryophyte species and genera, is xero-thermophilic (Frey \& Kürschner, 1988a, b), coinciding largely with areas of Mediterranean climate. The origin of such disjunctions has been the subject of some considerable interest, with the debate centred mainly on whether the disjunctions reflect recent dispersal or fragmentation of ancient ranges (for example, see Axelrod, 1973; Schofield, 1988; Fritsch, 2001; Shaw, Werner \& Ros, 2003). Frey and Kürschner (1988a, b) have included plants exhibiting such disjunctions in their xerothermic Pangean element thought to have originated in continental areas of Pangaea in Permo-Triassic times (about 220 mya). Disjunctions between European and western North American areas of Mediterranean climate have similarly been attributed to fragmentation of Madrean-Tethyan distributions about 20-25 mya (Axelrod, 1973). Thus, under such vicariance explanations, taxa exhibiting multi-centric distributions among areas of
Mediterranean climate would have to be ancient and, in the case of bryophyte species or morphologically poorly differentiated genera like Triquetrella, this implies long periods of evolutionary stasis (Crum, 1972).

Similarity in form is mirrored in the lack of molecular differentiation amongst species of the core Triquetrella group. This is particularly remarkable given that the DNA loci sampled here are used frequently for analyses at the population and individual level in most plant groups including mosses (e.g. Sang et al., 1997; Hedderson \& Nowell, 2006). The low levels of molecular and morphological divergence observed in this study argue against vicariance hypotheses and are consistent with recent establishment of the range of Triquetrella. Although the absence of suitable fossil data precludes direct calibration of the phylogenetic tree, application of molecular clocks can be useful and provide rough estimates of divergence times, even when certain assumptions of such methods are violated (see Bromham \& Penny, 2003). Based on published estimates for the regions sampled here (e.g. Bakker, Olsen \& Stam, 1995; McDaniel \& Shaw, 2003) divergence of the core Triquetrella clade began between 0.08 and 0.4 million years ago, whilst the split between $T$. mxinwana and $T$. paradoxa dates to 0.5-2.7 mya. Support for these dates comes from the strong association (Fig. 2) of Triquetrella mxinwana with the winter rainfall area of South Africa. This mega-niche, and much of the plant diversity within it, is thought to have existed only for the last two to five million years (Hendy, 1982; Deacon, 1983; Klak, Reeves \& Hedderson, 2004), a chronology highly consistent with our estimates.

Although our dating estimates may be problematic, for example we have made no attempt to account for phenomena such as rate variation across the tree, they highlight the fact that Xerothermic-Pangaean or MadreanTethyan, or indeed any other vicariance hypotheses that we are aware of, would require extremely unrealistic rates of substitution in all the markers evaluated. We would also point out that, given the position of Pottiaceae, and Triquetrella in particular, in recent DNA-based phylogenetic trees, attributing ages of more than a few million years to the genus would require pushing the origin of mosses to more than one billion years BP (T. A. Hedderson, unpublished), an unlikely scenario given currently accepted times for the origin of land plants. Rather, the current distribution of Triquetrella appears to be of PliocenePleistocene age and therefore the result of dispersal. Studies of various organisms exhibiting broadly similar patterns of distribution have reached the same conclusion (Coleman et al., 2003; Shaw et al., 2003; Tremetsberger et al., 2005).

A dispersalist hypothesis for Triquetrella may seem paradoxical given the rarity of sporophytes in the genus. However, the gametophytes fragment rather easily and seem to be the source of most new populations in at least the two South African species. In this region T. tristicha colonizes disturbed areas, such as road cuttings, very rapidly. At least some species produce gemmae (Casas 


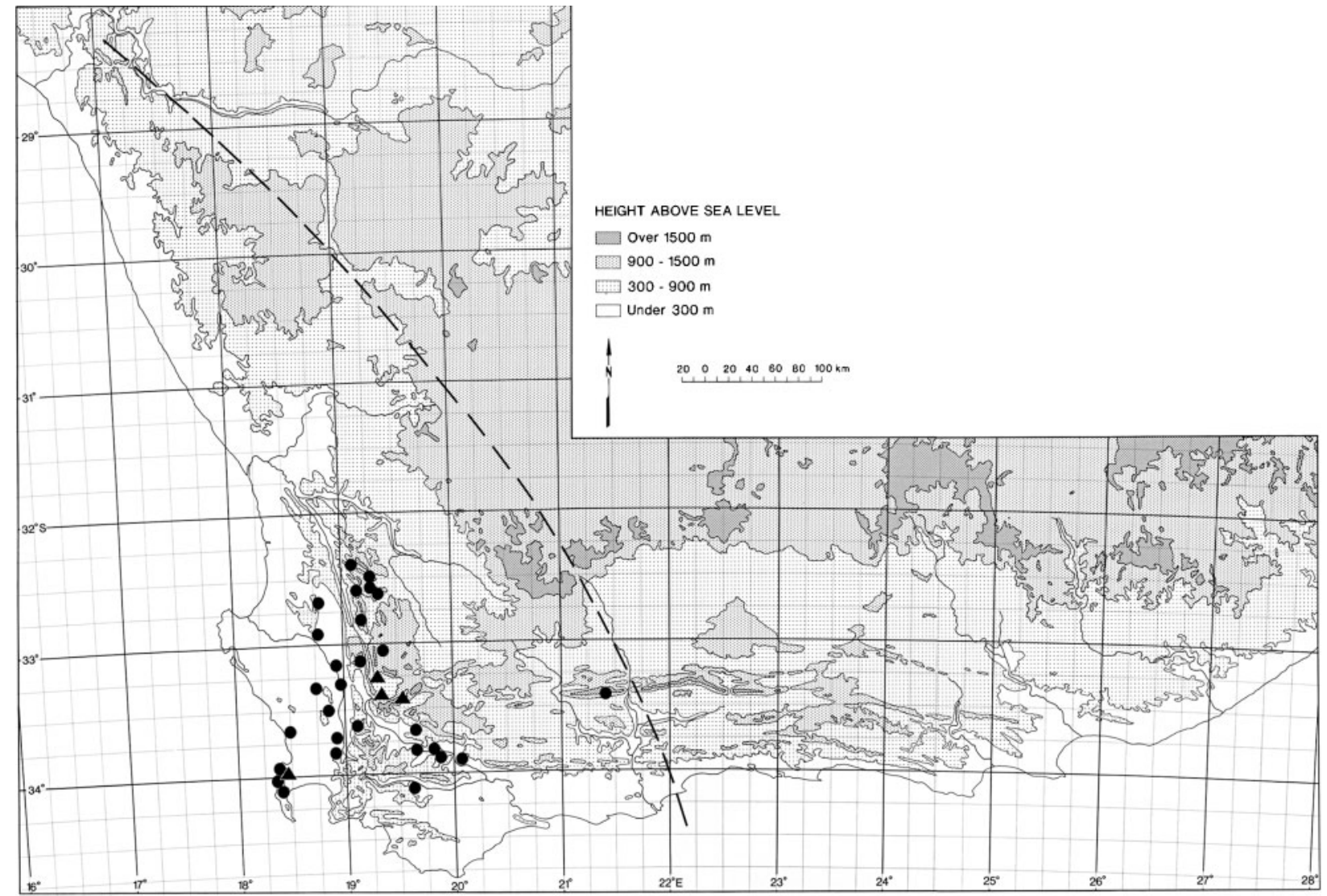

Figure 2. Map of southern and western South Africa showing the known distribution of Triquetrella mxinwana. Triangles indicate populations with sporophytes, and the dotted line indicates the approximate limit of the winter rainfall area, including some regions where rain may also fall in extreme late summer.

et al., 1993) and these may also serve a dispersal role. Furthermore, species of the genus are very drought tolerant (Moore, Luff \& Hallam, 1982) and gametophytes survive in a desiccated state for long periods. The combination of enhanced aridity and prevalent high winds that characterized some periods of the Pleiocene-Pleistocene (Stuut et al., 2002; Dupont et al., 2006; Chase \& Thomas, 2007) may have rendered these particularly favourable for dispersal of Triquetrella and perhaps other mosses. Of relevance here is the recent demonstration by Muñoz et al. (2004) that patterns of wind intensity and direction better explain floristic similarity in a range of plant groups among subAntarctic islands than does geographic proximity. An alternative, but perhaps less likely, explanation is that during wetter periods, sporophytes might be more commonly produced. Certainly for the two South African species, the few known fruiting populations show great inter-annual variation in sporophyte production that appears to correlate strongly with the amount and timing of rainfall.

Whatever the dispersal mechanism(s), it would be of interest to establish the ancestral area for the group as well as the frequency, direction and more precise timing of the implied dispersal events. The positions of the African and Australasian taxa in the phylogeny are consistent with a southern hemisphere origin for the genus. Although winter rainfall areas of Mediterranean climate are established by latitude-determined patterns of airflow, land corridors may previously have connected such areas of distinctive evolutionary challenge. The identical four-locus haplotypes shared by sampled individuals of the southern $T$. tristicha and the Mediterranean $T$. arapilensis suggest very recent movement between Southern Africa and the Mediterranean region. This may have occurred during periods of altered climate, such as the hypothermic phases of the late Quaternary (Petit et al., 1999; Prentice \& Jolly, 2000), perhaps via an eastern African arid corridor (Balinsky, 1962; Coleman et al., 2003). A similar situation exists with the $T$ californica-T. patagonica pair where, again, the identical haplotypes found in the two regions suggest recent (perhaps Holocene) dispersal. Given the low levels of divergence among the taxa, coalescent analyses of denser population samples could be used to test these hypotheses directly.

Taxonomic Treatment

Triquetrella paradoxa (I.G.Stone \& G.A.M.Scott) Hedd. \& R.H.Zander, comb. nov.

Basionym: Leptodontium paradoxum I. G. Stone \& G. A. M. Scott, J. Bryol. 11: 701. 1981. 
Type: Australia, Victoria, Mt Alexander, I.G. Stone 14550, 16 November 1978 (Isotype BM!).

Representative specimens examined:

AUSTRALIA: New South Wales, S of Goulburn, Crisp's Creek, Vitt 27377 (MO); South Australia, Mt Barker, H. Streimann 54794 (MO); Victoria, Flat Rock, Grampians National Park, H. Streimann 55251 (Musci Australasiae Exsiccati 569) (MO); Western Australia, Boyagin Rock, $H$. Streimann 54182 (Musci Australasiae Exsiccati 423) (MO).

Triquetrella mxinwana Hedd. \& R.H.Zander, sp. nov. (Fig. 3)

Plantae dense caespitosae. Caulis in sectione transversali rotundato-triangularis, filio centrali nullo, hyalodermide nulla, pilis axillaribus cellulis basalibus 1-2, parietibus tenuiter crassis. Folia tri-seriata, in statu madido late patentia vel patenti-recurva, ovato-triangularia, lamina superna carinata, marginibus in $2 / 3$ usque $3 / 4$ parte infera folii recurvis; margines basales foliares longe decurrentes; costa percurrens, epidermide ventrali nulla, filo hydroideo nullo; cellulae supernae laminales rotundato-rhombicae vel quadratae, leniter triangulae, papillis parvis humilibus bifidus per lumen 4-6; cellulae basales parum distinctae. Perichaetia terminalia, foliis interioribus ovatis vel ellipticis, valde setam vaginantia. Perigonia lateralia, ex axillis folii orta. Seta $0.9-1.5 \mathrm{~cm}$ longa. Capsula $1.0-1.8 \mathrm{~mm}$ longa, elliptica, annulo e cellulis vesciculosis in 3 series dispositis composito; dentes peristomii 16, usque ad basem fissi, obtuse subulati, hyaline vel pallide lutei, maximam partem leaves vel dentibus paucis pro parte leniter spiraliter striates. Calyptra laevis. Sporae $12-20 \mu \mathrm{m}$ diametro. Color laminae in $\mathrm{KOH}$ reagens luteus vel aurantiacus.

Type: South Africa, Western Cape Province, E. side of Skuurweberg, Fairfield Farm, 3319AD, Hedderson 15208, 27 August 2003 (holotype at BOL, isotype at MO).

Plants growing in dense mats, yellowish or blackish green above, brown or blackish brown below. Stems branching occasionally, to $2 \mathrm{~cm}$ in length, occasionally papillose, transverse section rounded-triangular to five-sided, central strand absent, sclerodermis present, of 1-3 layers of stereid cells, hyalodermis absent; axillary hairs 6-9 cells in length with cells weakly bulging, basal 1-2 cells very weakly thickwalled; sparsely radiculose below. Leaves in 3 distinct rows, the rows straight or weakly spiralling counter-clockwise, appressed-incurved to weakly spreading when dry, widely spreading to spreading-recurved when moist, ovatetriangular, $1.0-1.4(-1.7) \mathrm{mm}$ in length, upper lamina keeled, narrowly channelled along costa, margins recurved in lower $2 / 3$ to $3 / 4$ of leaf, entire; apex narrowly acute to short-acuminate; base ovate, basal leaf margins broadly long-decurrent; costa percurrent, superficial cells elongate and smooth or weakly papillose ventrally, rhombic-quadrate near apex and smooth or papillose dorsally, 2(-4) rows of cells across costa ventrally at midleaf, costal transverse section ovate to semicircular, ventral epidermis absent, dorsal stereid band usually absent, guide cells $2-4$ in 1 layer, hydroid strand absent, dorsal epidermis differentiated as thick-walled cells with semicircular lumens; upper laminal cells rounded-rhombic to quadrate, 8.4 $10.5 \mu \mathrm{m}$ in width, $1: 1$, occasionally elongate transversely, walls thickened, weakly trigonous, superficially weakly convex on both sides; papillae small, low, bifid, 4-6 per lumen; basal cells differentiated weakly as a single row of slightly elongate cells at leaf insertion. Dioicous. Perichaetia terminal but often appearing lateral because of sub-perichaetial inovation, inner leaves ovate to elliptic, to $2.2 \mathrm{~mm}$ in length, strongly sheathing seta, apex short-acuminate and reflexed, lower cells rhombic, upper cells narrowly rectangular to rhombic, thick-walled throughout. Perigonia lateral, borne in leaf axils; bracts ovate to nearly circular. Seta 0.9 $1.5 \mathrm{~cm}$ in length, 1 per perichaetium, yellow, twisted clockwise above. Capsule 1.0-1.8 $\mathrm{mm}$ in length, yellowish brown, elliptical, annulus of $c a 3$ rows of smaller, vesiculose cells; peristome teeth 16 , cleft to base, blunt, subulate, transparent or pale yellowish, mostly smooth or some teeth weakly spirally striate in part, $110-130 \mu \mathrm{m}$ in length, with ca 4-6 articulations, straight, basal membrane absent; operculum bluntly conic, $c a 0.5 \mathrm{~mm}$ in length, cells straight. Calyptra smooth, ca $2.2 \mathrm{~mm}$ in length. Spores ellipsoidal to spherical, $12-20 \mu \mathrm{m}$ in diameter, yellowish brown, finely papillose. Laminal $\mathrm{KOH}$ colour reaction yellow to orange.

The species epithet is derived from the isiXhosa adjectival -mxinwa, meaning narrow, and refers to the narrow leaves of this species compared with its congeners. It is correctly pronounced in isiXhosa as 'm(side-affricative)inwana', and in Latin it is pronounced 'm'ksinwana'; but, as usual, botanical Latin is acceptably pronounced according to one's native tongue.

Additional specimens examined (all at BOL unless otherwise indicated):

SOUTH AFRICA: Western Cape Province. Citrusdal Area, Cederberg, Algeria Forestry Station, 3219AC, Hedderson 13078. Citrusdal Area, Cederberg. Apex Peak, 3219CA, Hedderson 13620, 13653. Koue Bokkeveld Mountains, Twee Riviere, Suikerbossie Farm, 3219CB, Hedderson 13766. Oliphant's River Mountains, Berghof Farm, on margin of Groot Winterhoek Reserve, 3219CC, Hedderson 14025. Helderfontein Farm, ca $45 \mathrm{~km} \mathrm{~N}$. of Cape Town, 3318CB Townsend 82/289 (MO). Cape Peninsula, Table Mountain, between Window Gorge and Newland's Ravine, 3318CD, Hedderson 13813. Cape Peninsula, Table Mountain, North of Window Gorge, 3318CD, Hedderson 14986, c.fr. Table Mountain, Disa Ravine, 3318CD, Sim s.n. (PRE). Cape Peninsula, southern slopes of Lion's Head, 3318CD, Pillans 4088 (BOL, MO). Cape Peninsula, Camps Bay, Kloof Nek, road to the Round House, 3318CD, Townsend 82/58 (MO). Cape Peninsula, Table Mountain, Orange Kloof, 3318CD Hedderson 13539 (BOL, MO). Paarl, Paarl Rock, 3318DB, Garside 6621. Stellenbosch, Platklip, 3318DD Perold 463 (MO). Ceres Area, Op-die-Berg, 3319AB Morley 271 (MO). Worcester Division, Ceres Area, Theronsberg Pass, 3319AD, Linder s.n. BOL no. 32366, c.fr. Ceres Area, Waaihoek Berge, Trail through Waterval and Blokspring Kloofs, 3319AD, Hedderson 14426. Du 


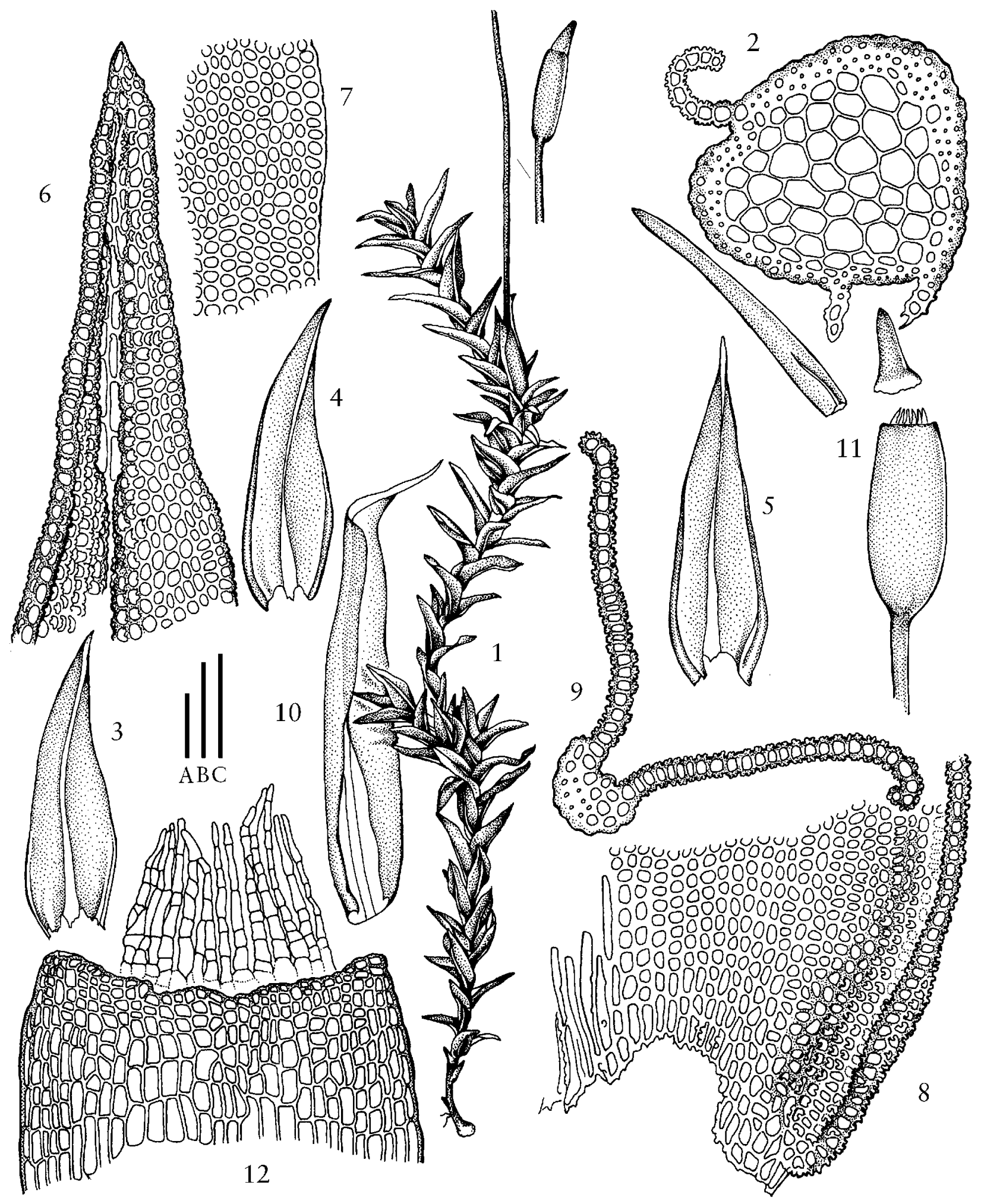

Figure 3. Triquetrella mxinwana: 1 , habit; 2 , transverse section of stem; $3-5$, leaves; 6 , leaf apex; 7, cells at mid-leaf; 8 , leaf base; 9 , transverse section at mid-leaf; 10, perichetial leaf; 11, capsule with operculum and calyptra; 12, peristome. Scale bars: A (1)=1 mm, B (3-5, 10, $11)=0.5 \mathrm{~mm}, \mathrm{C}(2,6-9,12)=50 \mu \mathrm{m}$.

Toits Kloof Pass, 3319CA, Hedderson 13266. Koo Valley, Simonsberg Farm, 3319DA, Hedderson 15463. Villiersdorp Area, Jonaskop, ca $35 \mathrm{~km} \mathrm{~S}$. of Worcester, 3319DC Townsend 82/279 (MO). Robertson Area, Dassie's Hoek
Nature Reserve, 3319DD, Hedderson 15557. Robertson, Klaas Vogdts West., Heuningberg, 3320CC, Hedderson 15523. Seven Weeks Port, N.E. of Ladismith, 3321AD, Magill 6153 (PRE). Cape Peninsula, Silvermine Nature 
Reserve, 3418AB, Hedderson 11698. Riviersonderend Mountains, McGregor Area, Boesman's Kloof, 3419BA, Hedderson 15242.

Habitat: The species is found in fynbos, succulent karoo and renosterveld vegetation (vegetation types follow Low, 1996). Most collections are from shales and granites, or clay soils derived from these substrates, and populations on sandstone soils in fynbos are mostly in transitional zones where there is admixture of either shale or granite. At higher altitudes, however, it occurs directly on sandstone, or in 'zuurvlakte' on deep, pure, quartzitic sands; 100-1400 m a.s.l.

Triquetrella mxinwana fits well into the complex of characters described above as characterizing the genus. Its peristome is quite unlike that of Leptodontium but characteristic of Triquetrella (see Zander, 1993). Triquetrella mxinwana differs most saliently from the majority of congeners by its low, bifid laminal papillae several occurring over each lumen. Furthermore, it is smaller, with stems to $2 \mathrm{~cm}$, not $7 \mathrm{~cm}$, in length; the central strand is never present; leaves are entire, never weakly serrulate above; the seta is $0.9-1.0 \mathrm{~cm}$ long while the seta of other species is generally $1.5-2.3 \mathrm{~cm}$ in length; and the theca is shorter, $1.0-1.2 \mathrm{~mm}$ as opposed to $1.6-2.1 \mathrm{~mm}$ in length.

In gametophytic traits it is similar to $T$. paradoxa, and like that species the stem section is occasionally 5-sided rather than 3-sided (as pointed out by Stone \& Scott, 1981). However, the two differ in a substantial number of traits as follows: plants of T. mxinwana as a whole are half the size, with leaves having about half the number of cells across the leaf and stems half the length; leaves are 1.9-2.8 times longer than broad (versus 2.8-3.5 times); elongate cells at the leaf base are few or absent (versus 3-5 rows of strongly elongate cells); distal laminal cells are larger, 8.4-10.5 $\mu \mathrm{m}$, with thick walls and somewhat irregular lumens (versus $6.0-8.5 \mu \mathrm{m}$, thin walls and smoothly rounded lumens); papillae are larger and more prominent (versus small and difficult to make out).

It is most readily (and unambiguously) distinguished from T. tristicha, the only other South African species, by the papilla character. With experience the two can also be separated reliably in the field since whilst the new species is shiny, T. tristicha is usually matte in appearance with a glaucous overtone to the yellowish colour. In addition the leaves of the latter are clearly ovate compared with the more distinctly triangular to ovate-lanceolate leaves of T. mxinwana.

Catcheside (1980) indicated that sporophytes are rare for this genus in South Australia, and Brotherus (1924, 1925) found it mostly sterile on a global level. The other South African species commonly has perigonia but only rarely fruits (Magill, 1981); sporophytes have been seen in only two populations. Both perichaetia and perigonia are present in $T$. mxinwana and a few specimens have sporophytes. Most of the sporulating specimens are from a small area of the Warm Bokkeveld, where some populations may fruit quite prolifically (as at the type locality, where there were hundreds of sporophytes), but a single sporophyte was also found in a population from the Cape Peninsula (Fig. 2).

Triquetrella mxinwana is currently known only from the winter rainfall area of the Western Cape Province (Fig. 2), but within this range it is rather common in certain habitats. For example, a recent study of remnant renosterveld vegetation in the Swartland region (Hedderson, Watson \& Rugengamanzi, unpublished) found it in about half of the surveyed fragments. It has been collected numerous times over the past century, and several specimens were found at BOL, MO and PRE marked as an unidentifiable species of Triquetrella, often including notes calling attention to the salient distinguishing feature, the small laminal papillae that occur several per lumen. Many specimens of T. mxinwana were identified by T. R. Sim as T. strictissima Rehm. ex Müll.Hal. However, examination of type material of that species (BM, H-Br) shows clearly that it is a synonym of T. tristicha as indicated by Magill (1981).

\section{ACKNOWLEDGEMENTS}

This research has been supported by grants from the University of Cape Town and from the National Research Foundation of South Africa. We would like to thank Gonzalo Aquilar for help with producing the map, Brian Chase for his ever incisive commentary on Quaternary climate, Patricia Eckel for executing the illustration and for rendering the Latin diagnosis, Ncumisa Mdingi for assistance with isiXhosa, and Tracey Nowell for generating the sequence data.

TAXONOMIC ADDITIONS AND CHANGES: Triquetrella paradoxa (I.G.Stone \& G.A.M.Scott) Hedd. \& R.H.Zander comb. nov. (syn. Leptodontium paradoxum I.G.Stone \& G.A.M.Scott); Triquetrella mxinwana Hedd. \& R.H.Zander sp. nov.

\section{REFERENCES}

Axelrod DI. 1973. Evolution and biogeography of the MadreanTethyan sclerophyll vegetation. Annals of the Missouri Botanic Garden 62: 280-334.

Bakker FT, Olsen JJ, Stam WT. 1995. Evolution of rDNA ITS sequences in the Cladophora albidalsericea clade (Chlorophyta). Journal of Molecular Evolution 40: 640-651.

Baldwin GB. 1992. Phylogenetic utility of the Internal Transcribed Spacers of nuclear ribosomal DNA in plants: an example from the Compositae. Molecular Phylogenetics and Evolution 1: 3-16.

Balinsky BI. 1962. Patterns of animal distribution on the African continent. Annals of the Cape Provincial Museum 11: 299-310.

Bromham L, Penny D. 2003. The modern molecular clock. Nature Reviews Genetics 4: 216-224.

Brotherus VF. 1924. Musci. In: Engler A, Prantl K, eds. Die Natürlichen Pflanzenfamilien, Band 10. Leipzig: W. Engelmann, 1-478.

Brotherus VF. 1925. Musci. In: Engler A, Prantl K, eds. Die Natürlichen Pflanzenfamilien, Band 11. Leipzig: W. Engelmann, 1-542.

Casas [de Puig] C, Cros RM, Muñoz J. 1993. Triquetrella arapilensis y especies afines: su morfología y distribución geográfica. Bryologist 96: $122-131$.

Catcheside DG. 1980. Mosses of South Australia. Handbook of the flora and fauna of South Australia. Adelaide: Flora and Fauna Handbooks Committee, Government Printer, South Australia. 
Chandler GT, Bayer RJ, Crisp MD. 2001. A molecular phylogeny of the endemic Australian genus Gastrolobium (Fabaceae: Mirbelieae) and allied genera using chloroplast and nuclear markers. American Journal of Botany 88: 1675-1687.

Chase B, Thomas DSG. 2007. Multiphase late Quaternary aeolian sediment accumulation in western South Africa: timing and relationship to palaeoclimatic changes inferred from the marine record. Quaternary International (in press).

Churchill SP, Griffin D, Muñoz J. 2000. A checklist of the mosses of the tropical Andean countries. Ruizia 17: 1-203.

Coleman M, Liston A, Kadereit JW, Abbott RJ. 2003. Repeat intercontinental dispersal and Pleistocene speciation in disjunct Mediterranean and desert Senecio (Asteraceae). American Journal of Botany 90: 1446-1454.

Cox CJ, Hedderson TA. 1999. Phylogenetic relationships among the ciliate arthrodontous mosses: evidence from chloroplast and nuclear DNA sequences. Plant Systematics and Evolution 215: 119-239.

Cox CJ, Hedderson TA. 2004. Phylogenetic relationships within the moss family Bryaceae based on chloroplast DNA evidence. Journal of Bryology 25: 31-40

Crum HA. 1972. The geographic origins of the mosses of North America's eastern deciduous forests. Journal of the Hattori Botanical Laboratory 35: 269-298.

Deacon HJ. 1983. An introduction to the Fynbos region, timescales and palaeoenvironments. In: Deacon HJ, Hendy QB, Lambrechts JJN, eds. Fynbos paleoecology: a preliminary synthesis. Cape Town: CSIR, 1-20.

Dupont LM, Donner B, Vidal L, Pérez EM, Wefer G. 2006. Linking desert evolution and coastal upwelling: Pliocene climate change in Namibia. Geology 33: 461-464.

Eddy A. 1990. A handbook of Malesian mosses. Vol. 2. Leucobryaceae to Buxbaumiaceae. London: Natural History Museum.

Farris JS, Albert VA, Källersjö M, Lipscomb D, Kluge AG. 1996. Parsimony jackknifing outperforms neighbor-joining. Cladistics 12: $99-124$

Frey W, Kürschner H. 1988a. Bryophytes of the Arabian Peninsula and Socotra. Floristics, phytogeography and definition of the Xerothermic Pangaean element, Studies in Arabian bryophytes 12. Nova Hedwigia 46: 37-120.

Frey W, Kürschner H. 1988b. Re-evaluation of Crossidium geheebii (Broth.) Broth. (Pottiaceae) from Sinai, a Xerothermic Pangaean element. Journal of Bryology 15: 123-126.

Fritsch P. 2001. Phylogeny and biogeography of the flowering plant genus Styrax (Styracaceae) based on chloroplast DNA restriction sites and DNA sequences from the internal transcribed spacer region. Molecular Phylogenetics and Evolution 19: 387-408.

Goffinet B, Cox CJ, Shaw AJ, Hedderson TA. 2001. The Bryophyta (Mosses): systematic and evolutionary inferences from a rps 4 gene (cpDNA) phylogeny. Annals of Botany 87: 191-208.

Hedderson TA, Murray D, Cox CJ, Nowell TL. 2004. Evolutionary relationships of the haplolepideous mosses inferred from rps4 gene sequences. Systematic Botany 29: 29-41.

Hedderson TA, Nowell TL. 2006. Phylogeography of Homalothecium sericeum (Hedw.) Br. Eur.; toward a reconstruction of glacial survival and post-glacial migration. Journal of Bryology 27: 283-292.

Hendy QB. 1982. Langebaanweg. A record of past life. Cape Town: South African Museum.

Klak C, Reeves G, Hedderson T. 2004. Unmatched tempo of evolution in Southern-African semi-desert ice plants. Nature 427: 63-65.

Low AB. 1996. Vegetation of South Africa, Lesotho and Swaziland. Pretoria: Department of Environmental Affairs and Tourism.

Magill R. 1981. Flora of Southern Africa. Bryophyta. Part 1. Mosses. Fascicle 1. Sphagnaceae-Grimmiaceae. Pretoria: Botanical Research Institute.
McDaniel SF, Shaw AJ. 2003. Phylogeographic structure and cryptic speciation in the trans-Antarctic moss Pyrrhobryum mnioides. Evolution 57: 202-215.

Moore CJ, Luff SE, Hallam ND. 1982. Fine-structure and physiology of the desiccation-tolerant mosses, Barbula torquata Tayl. and Triquetrella papillata (Hook f. and Wils.) Broth., during desiccation and rehydration. Botanical Gazette 143: 358-367.

Muñoz J, Felicisimo ÁM, Cabezas F, Burgaz AR, Martinez I. 2004. Wind as a long-distance dispersal vehicle in the Southern Hemisphere. Science 304: 1114-1147.

Nadot S, Bittar G, Carter L, LaCroix R, Lejeune B. 1995. A phylogenetic analysis of monocotyledons based on the chloroplast gene rps4, using parsimony and a new numerical phenetics method. Molecular Phylogenetics and Evolution 4: 257-282.

Petit JR, Jouzel J, Raynaud D, Barkov NI, Barnola JM, Basile I, Bender M, Chappellaz J, Davis M, Delaygue G, Delmotte M, Kotlyakov VM, Legrand M, Lipenkov VY, Lorius C, Pepin L, Ritz C, Saltzman E, Stievenard M. 1999. Climate and atmospheric history of the past 420,000 years from the Vostok ice core, Antarctica. Nature 399: 429-436.

Posada D, Crandall KA. 1998. Modeltest: testing the model of DNA substitution. Bioinformatics 14: 817-818.

Prentice IC, Jolly D. 2000. Mid-Holocene and glacial-maximum vegetation geography of the northern continents and Africa. Journal of Biogeography 27: 507-519.

Ronquist F, Huelsenbeck J. 2003. MrBayes 3: Bayesian phylogenetic inference under mixed models. Bioinformatics 19: 1572-1574.

Sang T, Crawford DJ, Stuessy TF. 1997. Chloroplast DNA phylogeny, reticulate evolution and biogeography of Paeonia (Paeoniaceae). American Journal of Botany 84: 1120-1136.

Schofield WB. 1988. Bryophyte disjunctions in the Northern Hemisphere: Europe and North America. Botanical Journal of the Linnaean Society 98: 211-224.

Shaw AJ, Werner O, Ros RM. 2003. Intercontinental Mediterranean disjunct mosses: morphological and molecular patterns. American Journal of Botany 90: 540-550.

Stark LR. 1980. Triquetrella in North America. Bryologist 83: 363 364.

Stone IG, Scott GAM. 1981 [1982]. Leptodontium paradoxum, a new moss from Australia. Journal of Bryology 11: 701-707.

Stuut J-BW, Prins MA, Schneider RR, Weltje GJ, Jansen JHF, Postma G. 2002. A $300 \mathrm{kyr}$ record of aridity and wind strength in southwestern Africa: inferences from grain-size distributions of sediments on Walvis Ridge, SE Atlantic. Marine Geology 180: 221233.

Swofford DL. 1998. PAUP*. Phylogenetic analysis using parsimony (and other methods). Version 4. Sunderland, MA: Sinauer.

Taberlet P, Gielly L, Pautou G, Bouvet J. 1991. Universal primers for the amplification of three non-coding regions of chloroplast DNA. Plant Molecular Biology 17: 1105-1109.

Tremetsberger K, Weiss-Schneeweiss H, Stuessy T, Samuel R, Kadlec G, Ortiz MA, Talavera S. 2005. Nuclear ribosomal DNA and karyotypes indicate a NW African origin of South American Hypochaeris (Asteraceae, Cichorieae). Molecular Phylogenetics and Evolution 35: 102-116.

Werner O, Ros RM, Cano MJ, Guerra J. 2004. Molecular phylogeny of Pottiaceae (Musci) based on chloroplast rps4 sequence data. Plant Systematics and Evolution 243: 147-164.

Zander RH. 1993. Genera of the Pottiaceae: mosses of harsh environments. Bulletin of the Buffalo Society for Natural Sciences 32: 1-378.

Zander RH. 2006. The Pottiaceae s.str. as an evolutionary Lazarus taxon. Journal of the Hattori Botanical Laboratory 100: 581-602.

Terry A. J. Hedderson, Bolus Herbarium, Department of Botany, University of Cape Town, Private Bag, 7701, Rondebosch, South Africa. E-mail thedders@egs.uct.ac.za

Richard H. ZANDER, Bryology Group, Missouri Botanical Garden, PO Box 299, St Louis, MO 63166, U.S.A. 